Volume 5 Number 2, July-December 2021: pg. 131-140.

Fakultas Hukum, Universitas Lampung,

Bandar Lampung, Lampung, Indonesia.

E-ISSN: 2598-3105 P-ISSN: 2723-2581

http://jurnal.fh.unila.ac.id/index.php/cepalo

\title{
THE BOARD OF DIRECTORS OF A BANKRUPT COMPANY'S CIVIL LIABILITY FOR OBTAINED TAXES
}

\author{
Nuki \\ Advocate, Law Office Nuki and Partners, Indonesia, \\ E-mail: nukiandpartners@ gmail.com
}

Submitted: June 11, 2021; Reviewed: July 14, 2021; Accepted: July 16, 2021

DOI: $10.25041 /$ cepalo.v5no2.2364

\begin{abstract}
Sumber Urip Sejati Utama Ltd. is a company that runs in the fertilizer industry. Technically, Sumber Urip Sejati Utama Ltd.'s board of directors purchase urea fertilizer for the factory, then sold the urea fertilizer to consumers. As a urea fertilizer distributor, Sumber Urip Sejati Utama Ltd. should fulfil tax administration obligations, such as reporting tax payments and calculations. However, Sumber Urip Sejati Ltd.'s administration is highly engineered by the company's directors because Sumber Urip Sejati Utama Ltd. is operating even though it is declared bankrupt. The situation escalades when the company is faced with unfulfilled tax obligation. Therefore, the main problem in this research is the director board of Sumber Urip Sejati Utama's Ltd. civil liability and legal consequences towards the tax in debt due to the board's negligence. The research method used in this study is a normative juridical approach, which is an approach based on the primary legal material by examining theories, concepts, legal principles and legislation. The research elaborates that the civil liability of Sumber Urip Sejati Utama Ltd.'s director board towards the tax in debts is in a form of joint responsibility or responsibility. Moreover, the legal consequences faced by the director boards due to their negligence is that directors should bear all of the company's debts to creditors and third parties, to the extent of using the directors' assets to cover the losses.
\end{abstract}

Keywords: Liability, Directors, Limited Liability Company, Bankruptcy, Taxes Payable.

\section{A. Introduction}

According to Article 1 paragraph (1) of Law Number 37 of 2004 Concerning Bankruptcy and Suspension of Debt Payment Obligations, bankruptcy is defined as the general confiscation of all assets of a bankrupt debtor whose management and settlement is carried out by a curator under the supervision of a supervisory judge as regulated in this law. Economic sector activities are now dominated by Limited Liability Companies. The fundamental problem with the bankruptcy of a company is that the problematic company could still operate or should be dissolved by law. Entrepreneurs widely use limited companies 
to run their businesses. ${ }^{1}$ In practice, the corporation's bankruptcy is also a bankruptcy for its directors because the implications of bankruptcy would follow the directors' board. After all, the company has limited liability for the shares owned. Shareholders have the option of selling shares of the company's assets to third-party investors. ${ }^{2}$

A company concept refers to capital/wealth based on shares. Simultaneously, the term limited refers to shareholders responsible for the shares they own. In contrast, the term company refers to a corporation or an association of shareholders committed to its business development. At the same time, Ltd. is a legal entity governed by limited liability company law. ${ }^{3}$ In carrying out its business, a limited liability company should adhere to its objectives and purposes and should not violate legal standards of decency and public order. ${ }^{4}$

Ltd. legal entities that conduct business as distributors selling urea fertilizer to third parties are extremely vulnerable to legal issues, especially regarding debts with third parties. Debts owed to third parties for the distributor's activities could be settled through a commercial court proceeding for bankruptcy. In that case, the directors' responsibilities may be transferred to the curator who manages the debtors' assets. ${ }^{5}$ They are supervised by a judge appointed as supervisor, including the obligations and responsibilities of the company's directors to third parties under Law Number 37 of 2004 Concerning Bankruptcy and Suspension of Debt Payment Obligations (Bankruptcy Law).

The General Meeting of Shareholders (GMS) determines the division of tasks and responsibilities of the directors' board elected and supervised by the commissioner under the company's articles of association. ${ }^{6}$ Furthermore, the forms of business entities run by entrepreneurs with legal entities, PT is an economic activity, also known as a corporate business, that includes industry, trade, distributors, and services. ${ }^{7}$ A Limited Liability Company could act as a private person who could carry out legal actions. However, the difference is that the board of directors represents the company, ${ }^{8}$ so the company attaches rights and obligations to the parties in conducting legal relations. ${ }^{9}$

One of the negligence committed by the company's directors is selling a urea fertilizer distributor. This impacts taxpayers with Ltd. legal entities responsibilities in the form of taxes

\footnotetext{
${ }^{1}$ Yudha Pradana, Hendro Saptono, and Etty Susilowati, "Kedudukan Ahli Waris Penanggung Perseorangan Pada Perseroan Terbatas Yang Dipailitkan Secara Bersama-Sama,” Diponegoro Law Journal 5, no. 3 (2016): 1-19, https://ejournal3.undip.ac.id/index.php/dlr/article/view/12382.

${ }^{2}$ Sri Redzeki Hartono, Kapita Selekta Hukum Perusahaan (Bandung: Mandar Maju, 2000): 5.

${ }^{3}$ Irwan Saleh Indrapradja, "Kajian Yuridis Terhadap Tanggung Jawab Direksi Dan Dewan Komisaris Pada Struktur Organisasi Perseroan Terbatas Yang Bersifat Kolegialitas Menurut Undang-Undang Nomor 40 Tahun 2007 Tentang Perseroan Terbatas," Jurnal Ilmiah Magister Administrasi 13, no. 1 (2019): 123-49, https://jurnal.unnur.ac.id/index.php/jimia/article/view/272.

${ }^{4}$ Agus Budiarto, Kedudukan Hukum Dan Tanggung Jawab Pendiri (Jakarta: PT. Ghalia Indonesia, 2002): 57.

${ }^{5}$ Yunintio Putro Utomo, "Kedudukan Perseroan Terbatas Yang Tetap Aktif Menjalankan Perusahaannya (Going Concern) Setelah Dipailitkan," Notarius 12, no. 2 (2019): 565-579, https://doi.org/10.14710/NTS.V12I2.28996.

${ }^{6}$ Dewi Tuti Muryati, B. Rini Heryanti, and Dharu Triasih, "Kajian Normatif Atas Kepailitan BUMN (Persero) Dalam Kaitannya Dengan Pengaturan Perseroan Terbatas," Jurnal Dinamika Sosial Budaya 17, no. 1 (2015): 29-40, https://doi.org/10.26623/JDSB.V17I1.500.

7 Musriansyah and Sihabudin, "Perlindungan Hukum Terhadap Pemegang Saham Dalam Penjualan Aset Perseroan Berdasarkan Pasal 102 Ayat (4) Undang-Undang Nomor 40 Tahun 2007 Tentang Perseroan Terbatas," Jurnal Ilmiah Pendidikan Pancasila Dan Kewarganegaraan 2, no. 2 (2017): 125-31, https://doi.org/10.17977/UM019V2I22017P125.

${ }^{8}$ Indah Restyaningrum, Budiharto, and Paramita Prananingtyas, "Tanggung Jawab Direksi Terhadap Kerugian Perseroan Akibat Penyalahgunaan Wewenang Direksi (Studi Kasus PT. Adi Partner Perkasa Putusan Nomor 313/PDT.G/2011/PN/JKT.SEL)," Diponegoro Law Journal $6, \quad$ no. $1 \quad$ (2017): 1-18, https://ejournal3.undip.ac.id/index.php/dlr/article/view/15635.

${ }^{9}$ Chatamarrasjid Ais, Penerobosan Cadar Perseroan Dan Soal-Soal Aktual Hukum Perusahaan (Bandung: Citra Aditya Bakti, 2004): 56.
} 
owed to the state, namely outcome taxes and income taxes from manufacturers to retailers. ${ }^{10}$ One of the negligences committed by the company's directors engaged in selling urea fertilizer handled by the Bengkulu and Lampung Regional Office of the Director-General of Taxes is Sumber Urip Sejati Utama Ltd.

The directors' board of Sumber Urip Sejati Utama Ltd., as the Taxable Entrepreneur, purchased urea fertilizer from the factory, which was subject to Value-added Tax (VAT), which is the Sumber Urip Sejati Utama Ltd.'s outcome tax. Then Sumber Urip Sejati Utama Ltd. sells the urea fertilizer to consumers. Every urea fertilizer purchaser is subject to VAT, which is Sumber Urip Sejati Utama Ltd.'s income tax. Furthermore, as a urea fertilizer distributor, Sumber Urip Sejati Utama Ltd. should fulfil tax administration obligations, such as reporting on tax payments and calculations, as outlined in the Notification of Annual Notification to the Pratama Tax Office.

Sumber Urip Sejati Utama Ltd. sells urea fertilizer to third parties by issuing input tax invoices. Then it reports and deposits to the Pratama Tax Office without regard for the actual transaction and notifies a warning and/or information to the Primary Tax Office. The reports' contents do not match the data manipulated by the taxpayer, resulting in a loss of tax revenue for the state. Furthermore, the tax office discovered evidence of Sumber Urip Sejati Utama Ltd. negligence, such as issuing tax notes that did not correspond to actual transactions and sending notifications with fictitious content. The Pratama Tax Office then reported the negligence to the Directorate General of Taxes' Bengkulu and Lampung Regional Offices, followed by the preliminary evidence examination stage or bukti permulaan (buper) to audit the Sumber Urip Sejati Utama Ltd.'s taxpayers. However, during the Buper inspection by Civil Servant Investigators at the Directorate General of Taxes' Bengkulu and Lampung Regional Offices, Sumber Urip Sejati Utama Ltd. declared bankruptcy.

Sumber Urip Sejati Utama Ltd. acted as the urea fertilizer sales' distributor, selling urea fertilizer directly to consumers before receiving an income tax invoice through fictitious transactions to avoid paying state taxes. If the Commercial Court declares Sumber Urip Sejati Utama Ltd. bankrupt, all tax obligations owed by the company would be transferred to the curator. The state has rights and obligations over the Taxpayer Sumber Urip Sejati Utama Ltd.'s assets under Law No. 28 of 2007 concerning General Provisions and Tax Procedures (KUP). This is also regulated in the Bankruptcy Law that the state has the right to claim against the bankrupt debtor and precede other bankrupt creditors or often referred to as Preferred Creditors. In this case, the State, represented by a Civil Servant Investigator at the Directorate General of Taxes' Bengkulu and Lampung Regional Offices, has the authority to collect the taxes owed by Sumber Urip Sejati Utama Ltd. However, they do not apply as a preferred creditor on the Taxpayer Sumber Urip Sejati Utama Ltd.'s assets (Bankrupt Debtor) to the curator. Civil Servant Investigators at the Directorate General of Taxes' Bengkulu and Lampung Regional Offices tend to continue the case to the investigation level.

Based on the description, the research identifies problems on two main issues: (1) the civil liability of Sumber Urip Sejati Utama Ltd.'s director board towards taxes in debt and (2) the legal consequences faced by Sumber Urip Sejati Utama Ltd.'s Director Board towards the taxes in Debt due to Negligence. The research method employs a normative juridical approach, which investigates theories, concepts, legal principles, and relevant laws and regulations.

\footnotetext{
${ }^{10}$ Mayazitha Reggina Geruh, "Penerapan Akuntansi Terhadap Pajak Pertambahan Nilai Pada Pengusaha Kena Pajak," Jurnal EMBA: Jurnal Riset Ekonomi, Manajemen, Bisnis Dan Akuntansi 1, no. 3 (2013): 1-9, https://doi.org/10.35794/EMBA.1.3.2013.1367.
} 


\section{B. Discussion}

\section{Civil Liability of Sumber Urip Sejati Utama Ltd.'s Director Board towards the Taxes in Debt}

A Limited Liability Company is a legal entity consisting of GMS, Directors, and Commissioners, with all members sharing capital. This is confirmed in Article 1 point 1 of the Limited Liability Company Law, which defines a Limited Liability Company as a legal entity established by agreement with partner members willing to invest capital in the form of shares to seek profit as stipulated by statutory regulation. ${ }^{11}$ Information system (IS) procurement in the public sector is a strictly regulated process that has raised numerous concerns. $^{12}$

Regarding a Limited Liability Company's bankruptcy caused by the Board of Directors' fault or negligence, Article 104 paragraph (2) of the Limited Liability Company Law emphasizes that the Board of Directors has personal or joint responsibility for the bankrupt company. Politics and public policies significantly influence, change or shape the business environment and consequently affect the viability and performance of the company. ${ }^{13}$ Therefore, all directors are responsible to the company they lead, with any negligence resulting in the directors' board bearing all of the company's debts to creditors and third parties by using the directors' assets to cover the losses caused by their actions. ${ }^{14}$

For example, Sumber Urip Sejati Utama Ltd.'s directors act as a distributor of urea fertilizer to consumers. Then, Sumber Urip Sejati Utama Ltd. appeared to have received a tax invoice from consumers, issued a tax note, and made a notice with fictitious substance to reduce its obligation to pay taxes to the state, resulting in a loss of tax revenue for the state. In fact, the Commercial Court determined that Sumber Urip Sejati Utama Ltd. was bankrupt. In contrast, corporate legal jurisprudence is quantitatively dominated by several legal issues around one type of contract that allows consumers to become company shareholders. ${ }^{15}$

The description above indicates that the Sumber Urip Sejati Utama Ltd.'s directors committed irregularities, so Article 104 paragraphs (2) and (3) of the Company Law apply unless the directors could prove:

a. The bankrupt company is not the board of directors' fault or negligence;

b. The Board of Directors has attempted to do the best for the company, as evidenced by the prudence, good faith, and responsibility;

c. The Board of Directors has no conflict of interest in managing the legal entity or company they lead;

d. The board of directors seeks to prevent bankruptcy.

Since the company became a legal entity, the directors have had responsibilities and burdens to shareholders. ${ }^{16}$ If the Board of Directors acts on the company's behalf, the Board

\footnotetext{
${ }^{11}$ M. Yahya Harahap, Hukum Perseroan Terbatas (Jakarta: Sinar Grafika, 2011): 1-600.

12 Elina Riihimäki and Samuli Pekkola, "Public Buyer's Concerns Influencing the Early Phases of Information System Acquisition," Government Information Quarterly 38, no. 4 (2021): 1-11, https://doi.org/10.1016/J.GIQ.2021.101595.

13 Tahiru Azaaviele Liedong, "The Liability of Tribe in Corporate Political Activity: Ethical Implications for Political Contestability," Journal of Business Ethics, 2021, 1-22, https://doi.org/10.1007/S10551-021-04889-Y.

${ }^{14}$ Christania Vanessa Sengkey, "Kajian Hukum Terhadap Penerapan Good Corporate Governance Berdasarkan Undang-Undang Nomor 40 Tahun 2007 Tentang Perseroan Terbatas," Lex Administratum 6, no. 1 (2018): 14451, https://ejournal.unsrat.ac.id/index.php/administratum/article/view/20346.

15 José Luiz Nunes and Ivar A. Hartmann, "A Quantitative Approach to Ranking Corporate Law Precedents in the Brazilian Superior Court of Justice," Artificial Intelligence and Law, 2021, 1-29, https://doi.org/10.1007/S10506-021-09290-8.

${ }^{16}$ Verina Yuwono Setianto, "Pertanggungjawaban Pribadi Direksi Pada Perseroan Terbatas Yang Pailit," Mimbar Yustitia 1, no. 2 (2017): 202-22, https://doi.org/10.52166/MIMBAR.V1I2.1139.
} 
of Directors has obligations to fulfil. Negligence in carrying out its obligations to provide sanctions imposes liability to the Board of Directors. ${ }^{17}$ The fictional theory declares corporations to be legal fiction, formless and could not do their will. Humans represent legal entities, so what they do is the same as what humans do. If humans are responsible for their actions, then legal entities could also be held responsible. ${ }^{18}$ Fundamentally, an individual's capacity to form and maintain an identity depends on his ability to select and prioritize information about himself. ${ }^{19}$

Based on the understanding of bankruptcy, if it is proven that the board of directors has a responsibility or joint responsibility for the bankrupt company due to irregularities committed. Therefore, all directors are responsible to the company they lead with any negligence committed to providing legal consequences for the board of directors. Moreover, they used the directors' assets to cover up loans, including a tax debt issued with a tax assessment letter.

As a preferred creditor, the state has the authority to collect debts owed by debtors (taxpayers), which would be auctioned in public and used to fund state taxes. ${ }^{20}$ The debt to other creditors is paid off after the tax debt is paid off. When the company is declared bankrupt, the board of directors is obligated to pay the tax, as confirmed by the absolute tax liability theory (the theory of devotion), which is based on the understanding of the Organische Staatsleer. The state has the right to collect taxes from its citizens under this understanding. Society transformed into a state because it could not function independently. In essence, every society recognizes the importance of unity in a country's development. The state could not exist without the people, and the people could not live in prosperity unless the state facilitates them. Hence, it becomes an absolute obligation to demonstrate its form of service to the state through tax contributions. ${ }^{21}$

If the board of directors could prove that they did not deviate and make a mistake, the shareholders and the company would bear the loss to the extent of their assets. In this case, the board of directors is unaccounted for. However, the founders and shareholders could account for the assets deposited into the company.

\section{Legal Consequences Faced by Sumber Urip Sejati Utama Ltd.'s Director Board towards the Taxes in Debt Due to Negligence}

The board of directors is responsible for running the company based on principles such as upholding its trust and being accountable for carrying out every policy and action. ${ }^{22}$ This principle emphasizes the board of directors to uphold these two principles for the benefit and progress of the company. Directors who violate these two principles face legal consequences and liability if the company suffers losses, as stated in Articles 97 and 104 of the Company Law. In principle, the board of directors has limited liability, except that the liability becomes unlimited and would target the directors personally, due to the following two things:

\footnotetext{
17 Tengku Erwinsyahbana, "Pertanggungjawaban Yuridis Direksi Terhadap Risiko Kerugian Keuangan Daerah Pada Badan Usaha Milik Daerah," De Lega Lata: Jurnal Ilmu Hukum 2, no. 1 (2017): 183-212, https://doi.org/10.30596/DLL.V2I1.1145.

18 Gunawan Wijaya, Tanggung Jawab Direksi Atas Kepailitan Perseroan (Jakarta: PT Raja Grafindo Persada, 2004): 21.

19 Bart van der Sloot, "The Right to Be Let Alone by Oneself: Narrative and Identity in a Data-Driven Environment," Law, Innovation and Technology 13, no. 1 (2021): 223-55, https://doi.org/10.1080/17579961.2021.1898315.

${ }^{20}$ Hamdi, Sulaiman, and Teuku Yudi Afrizal, "Perlindungan Hukum Bagi Kreditor Terhadap Pelunasan Piutang Dari Harta Pailit," Jurnal Ilmiah Mahasiswa Fakultas Hukum 1, no. 1 (2018): 20-37, https://doi.org/10.29103/jimfh.v1i1.2541.

${ }^{21}$ Siti Resmi, Perpajakan: Teori Dan Kasus, 8th ed. (Jakarta: Salemba Empat, 2014): 6.

${ }^{22}$ Ais, Penerobosan Cadar Perseroan Dan Soal-Soal Aktual Hukum Perusahaan.
} 
a. Piercing The Corporate Veil was adopted by countries with common law understanding, such as America and England. Still, along with the development of Piercing the Corporate Veil, it has penetrated the civil law system, namely the Netherlands and France. ${ }^{23}$ Piercing The Corporate Veil teaches that a company or legal entity only has the liability to the extent of its assets. However, in certain circumstances, the liability could be penetrated so that the company's liability is increasingly unlimited. For example, the facts of piercing the corporate veil doctrine are an inappropriate source of capital, using company funds or assets in a way against the law, unable to show and have legal documents for legal entities, and the existence of elements of fraud by abusing legal entities. $^{24}$

b. Ultra Vires, namely if the directors running the company have violated their primary duties determined in the articles of association. The consequences of their actions should be responsible for their assets. ${ }^{25}$ The point is that Ultra Vires is an act of directors that exceeds the limit and violates the company's articles of association. ${ }^{26}$

According to Article 92 paragraph (2) of the Company Law, The directors should follow the duties and policies when running the company, relying on the articles of association and the law. The Board of Directors is liable to the company they lead for negligence committed as a legal result of its responsibility. As stated in Article 97 paragraph (3) of the Company Law, the board of directors should act in good faith and take full responsibility for all actions taken for the company's advancement. ${ }^{27}$ By implementing these two principles, the board of directors has limited liability, which is a characteristic of the legal entity. If these two principles are not followed, the directors take responsibility for significant losses for the company they lead.

Based on this case, Sumber Urip Sejati Utama Ltd. acts as a urea fertilizer sales distributor that sells urea fertilizer directly to consumers and receives a tax invoice on fertilizer sales with fraudulent transactions, issuing a Notification Letter and/or providing incorrect information. However, Sumber Urip Sejati Utama Ltd. was declared bankrupt by the Commercial Court. The legal consequence is that the Board of Directors is personally responsible for any loss to the company for not implementing the principles in good faith and with full responsibility, thereby violating Piercing The Corporate Veil and ultra vires.

Review of the Business Judgment Rule theory, one of the most popular theories for ensuring justice for good-intentioned directors. ${ }^{28}$ This theory's application has the primary goal of achieving justice, particularly for the directors of a limited company when making a business decision, implying that the Board of Directors has no personal interest in the company's operation. ${ }^{29}$ Whereas in facilitating the state's needs, taxes are also required to

\footnotetext{
${ }^{23}$ Munir Fuady, Doktrin-Doktrin Modern Dalam Corporate Law (Bandung: Citra Aditya Bakti, 2002): 7.

${ }^{24}$ Munir Fuady, Hukum Perusahaan Dalam Paradigma Hukum Bisnis (Bandung: Citra Aditya Bakti, 2002$)$ ) 43.

${ }^{25}$ Chatamarrasjid Ais, "Ultra Vires Dan Pertanggungjawaban Direksi," Jurnal Hukum \& Pembangunan 32, no. 3 (2017): 328-41, https://doi.org/10.21143/JHP.VOL32.NO3.1343.

${ }^{26}$ Fred B.G. Tumbuan, "Pendirian Perseroan Terbatas Dan Pertanggungjawaban Direksi Dan Dewan Komisaris Serta Pihak Terkait Lainnya," in Seminar Dengar Pendapat Publik Berkenaan Dengan Perubahan Aspek Hukum Perseroan Terbatas, 2000, 3.

${ }^{27}$ I.G. Rai Widjaya, Hukum Perusahaan (Bekasi: Kesaint Blanc, 2003): 1-615.

28 Muhammad Gary Gagarin Akbar, "Business Judgement Rule Sebagai Perlindungan Hukum Bagi Direksi Perseroan Dalam Melakukan Transaksi Bisnis," Justisi Jurnal Ilmu Hukum 1, no. 1 (2016): 1-15, https://doi.org/10.36805/JJIH.V1I1.77.

${ }^{29}$ Syarif Bastaman, "Tanggung Jawab Direksi, Komisaris PT Dan Beberapa Prinsip Penting Di Dalam UU No. 1 Tahun 1995" (Jakarta, 1996): 5.
} 
contribute to long-term fiscal capacity if borrowers interfere with debt payments and as part of the default settlement. ${ }^{30}$

According to the author's research, the Directors of Sumber Urip Sejati Utama Ltd. abused their authority over the company when it declared bankruptcy. Sumber Urip Sejati Utama Ltd.'s Board of Directors also acted in bad faith, causing the state to suffer by issuing tax notes that did not correspond to actual transactions and notifications with fictitious substance. As a result, the legal ramification is a negligence of Article 39 A of the KUP, which states that "A taxpayer who is indicated by issuing a tax note that is not the same as the actual transaction and notifying with a fictitious substance shall be punished with imprisonment for a minimum of 2 (two) years and a maximum 6 (six) years and a fine of 2 times the amount of tax in the tax withholding proof of the tax invoice, proof of tax collection, and/or proof of tax payment".

\section{Conclusion}

Civil liability of the directors of Sumber Urip Sejati Utama Ltd., who was declared bankrupt against the tax payable arising from negligence committed by the board of directors, namely having joint responsibility or responsibility. Therefore, the legal consequences are that all directors should bear all of the company's debts to creditors and third parties, even if a tax debt has been issued with a tax assessment letter, using the directors' assets to cover the losses. The state has the authority to collect debts owed by debtors (taxpayers), whose debts would be auctioned publicly and become state income for taxes. The board of directors of Sumber Urip Sejati Utama Ltd.'s negligence did not compliment principles of piercing the corporate veil and Ultra Vires.

\section{REFERENCES}

Ais, Chatamarrasjid. Penerobosan Cadar Perseroan Dan Soal-Soal Aktual Hukum Perusahaan. Bandung: Citra Aditya Bakti, 2004: 56.

" "Ultra Vires Dan Pertanggungjawaban Direksi." Jurnal Hukum \& Pembangunan 32, no. 3 (2017): 328-41. https://doi.org/10.21143/JHP.VOL32.NO3.1343.

Akbar, Muhammad Gary Gagarin. "Business Judgement Rule Sebagai Perlindungan Hukum Bagi Direksi Perseroan Dalam Melakukan Transaksi Bisnis.” Justisi Jurnal Ilmu Hukum 1, no. 1 (2016): 1-15. https://doi.org/10.36805/JJIH.V1I1.77.

Bastaman, Syarif. "Tanggung Jawab Direksi, Komisaris PT Dan Beberapa Prinsip Penting Di Dalam UU No. 1 Tahun 1995." Jakarta, 1996: 5.

Budiarto, Agus. Kedudukan Hukum Dan Tanggung Jawab Pendiri. Jakarta: PT. Ghalia Indonesia, 2002: 57.

Erwinsyahbana, Tengku. "Pertanggungjawaban Yuridis Direksi Terhadap Risiko Kerugian Keuangan Daerah Pada Badan Usaha Milik Daerah.” De Lega Lata: Jurnal Ilmu Hukum 2, no. 1 (2017): 183-212. https://doi.org/10.30596/DLL.V2I1.1145.

Fuady, Munir. Doktrin-Doktrin Modern Dalam Corporate Law. Bandung: Citra Aditya Bakti, 2002: 7.

\footnotetext{
${ }^{30}$ Didac Queralt, "War, International Finance, and Fiscal Capacity in the Long Run,” International Organization 73, no. 4 (2019): 713-53, https://doi.org/10.1017/S0020818319000250.
} 
Hukum Perusahaan Dalam Paradigma Hukum Bisnis. Bandung: Citra Aditya Bakti, 2002: 43.

Geruh, Mayazitha Reggina. "Penerapan Akuntansi Terhadap Pajak Pertambahan Nilai Pada Pengusaha Kena Pajak." Jurnal EMBA: Jurnal Riset Ekonomi, Manajemen, Bisnis Dan Akuntansi 1, no. 3 (2013): 1-9. https://doi.org/10.35794/EMBA.1.3.2013.1367.

Hamdi, Sulaiman, and Teuku Yudi Afrizal. "Perlindungan Hukum Bagi Kreditor Terhadap Pelunasan Piutang Dari Harta Pailit.” Jurnal Ilmiah Mahasiswa Fakultas Hukum 1, no. 1 (2018): 20-37. https://doi.org/10.29103/jimfh.v1i1.2541.

Harahap, M. Yahya. Hukum Perseroan Terbatas. Jakarta: Sinar Grafika, 2011: 1-600.

Hartono, Sri Redzeki. Kapita Selekta Hukum Perusahaan. Bandung: Mandar Maju, 2000: 5.

Indrapradja, Irwan Saleh. "Kajian Yuridis Terhadap Tanggung Jawab Direksi Dan Dewan Komisaris Pada Struktur Organisasi Perseroan Terbatas Yang Bersifat Kolegialitas Menurut Undang-Undang Nomor 40 Tahun 2007 Tentang Perseroan Terbatas." Jurnal Ilmiah Magister Administrasi 13, no. 1 (2019): 123-49. https://jurnal.unnur.ac.id/index.php/jimia/article/view/272.

Liedong, Tahiru Azaaviele. "The Liability of Tribe in Corporate Political Activity: Ethical Implications for Political Contestability." Journal of Business Ethics, 2021, 1-22. https://doi.org/10.1007/S10551-021-04889-Y.

Muryati, Dewi Tuti, B. Rini Heryanti, and Dharu Triasih. "Kajian Normatif Atas Kepailitan BUMN (Persero) Dalam Kaitannya Dengan Pengaturan Perseroan Terbatas." Jurnal Dinamika Sosial Budaya 17, no. 1 (2015): 29-40. https://doi.org/10.26623/JDSB.V17I1.500.

Musriansyah, and Sihabudin. "Perlindungan Hukum Terhadap Pemegang Saham Dalam Penjualan Aset Perseroan Berdasarkan Pasal 102 Ayat (4) Undang-Undang Nomor 40 Tahun 2007 Tentang Perseroan Terbatas." Jurnal Ilmiah Pendidikan Pancasila Dan $\begin{array}{lllll}\text { Kewarganegaraan } & 2, & \text { no. } & 2 & \text { (2017): }\end{array}$ https://doi.org/10.17977/UM019V2I22017P125.

Nunes, José Luiz, and Ivar A. Hartmann. "A Quantitative Approach to Ranking Corporate Law Precedents in the Brazilian Superior Court of Justice." Artificial Intelligence and Law, 2021, 1-29. https://doi.org/10.1007/S10506-021-09290-8.

Pradana, Yudha, Hendro Saptono, and Etty Susilowati. "Kedudukan Ahli Waris Penanggung Perseorangan Pada Perseroan Terbatas Yang Dipailitkan Secara Bersama-Sama." $\begin{array}{lllllll}\text { Diponegoro Law Journal } & \text { 5, no. } 3 & \text { (2016): }\end{array}$ https://ejournal3.undip.ac.id/index.php/dlr/article/view/12382.

Queralt, Didac. "War, International Finance, and Fiscal Capacity in the Long Run." International Organization 73, no. 4 (2019): $713-53$. https://doi.org/10.1017/S0020818319000250.

Resmi, Siti. Perpajakan: Teori Dan Kasus. 8th ed. Jakarta: Salemba Empat, 2014: 6.

Restyaningrum, Indah, Budiharto, and Paramita Prananingtyas. "Tanggung Jawab Direksi Terhadap Kerugian Perseroan Akibat Penyalahgunaan Wewenang Direksi (Studi Kasus PT. Adi Partner Perkasa Putusan Nomor 313/PDT.G/2011/PN/JKT.SEL).” Diponegoro 
$\begin{array}{lllllll}\text { Law } & \text { Journal } & 6, & \text { no. } & 1 & \text { (2017): } & 1-18 .\end{array}$ https://ejournal3.undip.ac.id/index.php/dlr/article/view/15635.

Riihimäki, Elina, and Samuli Pekkola. "Public Buyer's Concerns Influencing the Early Phases of Information System Acquisition." Government Information Quarterly 38, no. 4 (2021): 1-11. https://doi.org/10.1016/J.GIQ.2021.101595.

Sengkey, Christania Vanessa. "Kajian Hukum Terhadap Penerapan Good Corporate Governance Berdasarkan Undang-Undang Nomor 40 Tahun 2007 Tentang Perseroan Terbatas." Lex Administratum 6, no. 1 (2018): 144-51. https://ejournal.unsrat.ac.id/index.php/administratum/article/view/20346.

Setianto, Verina Yuwono. "Pertanggungjawaban Pribadi Direksi Pada Perseroan Terbatas Yang Pailit." Mimbar Yustitia 1, no. 2 (2017): 202-22. https://doi.org/10.52166/MIMBAR.V1I2.1139.

Sloot, Bart van der. "The Right to Be Let Alone by Oneself: Narrative and Identity in a DataDriven Environment." Law, Innovation and Technology 13, no. 1 (2021): 223-55. https://doi.org/10.1080/17579961.2021.1898315.

Tumbuan, Fred B.G. "Pendirian Perseroan Terbatas Dan Pertanggungjawaban Direksi Dan Dewan Komisaris Serta Pihak Terkait Lainnya." In Seminar Dengar Pendapat Publik Berkenaan Dengan Perubahan Aspek Hukum Perseroan Terbatas, 3, 2000.

Utomo, Yunintio Putro. "Kedudukan Perseroan Terbatas Yang Tetap Aktif Menjalankan Perusahaannya (Going Concern) Setelah Dipailitkan.” Notarius 12, no. 2 (2019): 565579. https://doi.org/10.14710/NTS.V12I2.28996.

Widjaya, I.G. Rai. Hukum Perusahaan. Bekasi: Kesaint Blanc, 2003: 1-615.

Wijaya, Gunawan. Tanggung Jawab Direksi Atas Kepailitan Perseroan. Jakarta: PT Raja Grafindo Persada, 2004: 21. 
